\title{
Measuring the Effectiveness of Banking Risk Balanced Scorecard in Enhancing Bank Value
}

\author{
Sayed M. Elkhouly ${ }^{1}$, Mohamed M. Ibrahim ${ }^{2}$, Mohamed M. El Frargy ${ }^{3}$ \& Amal S. Kotb ${ }^{4}$ \\ ${ }^{1}$ Ain Shams University, Egypt \\ ${ }^{2}$ Higher Institute for Managerial Science, Egypt \\ ${ }^{3}$ Modern Academy, Egypt \\ ${ }^{4}$ Egyptian Banking Institute, Egypt \\ Correspondence: Mohamed M. Ibrahim, Higher Institute for Managerial Science, Cairo, Egypt. Tel: \\ 100-798-1524. E-mail: mohamed_mahmoud2k@yahoo.com
}

Received: February 11, 2015

doi:10.5539/ijef.v7n6p139
Accepted: March 23, 2015

Online Published: May 25, 2015

URL: http://dx.doi.org/10.5539/ijef.v7n6p139

\begin{abstract}
The purpose of this paper is to contribute to the body of knowledge in the area of risk balanced scorecard, particularly in the banking sector which faces variety complex types of risk. The authors develop a conceptual framework for measuring the effectiveness of Banking Risk Balanced Scorecard (BRBS) across and beyond Basel requirementsin addition to its essential role to maximize both of stakeholders' value and competitive advantage. Stakeholders include shareholder value (investors) and intellectual capital (customers, employees and regulators). Competitive advantage can be measured by the market share, as a proxy of it. The authors adopt quantitative approach for this purpose.
\end{abstract}

Keywords: banking risk balanced score card, basel requirements, market based measures, economic value added, Tobin's Q, market share

\section{Introduction}

There is not a universal definition of risk; every author addresses the risk from a different perspective. Traditionally it has been defined in terms of the possibility of danger (Collier \& Gay, 2005).

Gallati (2003) defines risk as a condition in which there exist an exposure to a diversity, or a condition in which there exists a possibility of deviation from a desired outcome that is expected or hoped for. To be more precise, it can be defined, as in finance, the volatility emanating from the market that cannot be diversified away (Sharpe, 1964). Unlike the field of goods, services industries are governed by the philosophy of process- based orientation, in the sense that every service industry is concerned with a set of characteristics that reflect a range of risks associated with the main features of this industry, which may not fit to the application of the same measures for risk.

The concept of risk was explicitly appeared for the first time in finance by the Nobel award winner, Harry Markowitz, he argued to include riskin the portfolio and diversification discussion, as well as, he linked terms such as return and utility with the concept of risk (Markowitz, 1952).

In banks, risks are usually defined by the adverse impact on profitability of several distinct sources of uncertainties (Bessis, 1998). The unique nature of the banking industry, as financial intermediator, doesn't leads only to besubject to a wide array of risks, but the risk is in the core of its business. The bank is a "risk machine", it takes risk, it transforms them, and it embedded them in banking products and services (Bessis, 1998).

As the same pace of risk definition, literature shows different classifications of risks. There is an important distinction between measurable risk and subjective, perceived risk, by other words ,risk can be thought about by reference to the existence of internal or external events (Collier et al., 2007).banks in the process of acting as intermediaries are confronted with various kind of financial \& non-financial risk (Srivastav, 2013). In the banking universe, risks are multidimensional. The main banking risks are credit risk, market risk, liquidity risk and operational risk (Bessis, 1998). 


\section{Literature Review}

Risks and doing business go hand in hand since the beginning of humanity. The roots of risk management can be found in corporate insurance industry (Collier et al., 2007). The concept of risk management was first introduced into business strategy in 1916 by Henry Fayol. But it became formalized after (Gallagher, 1956) published his article "Risk Management: A new Phase of Cost Control" and argued that the professional insurance manager should be a risk manager.

Risk management can be regarded as an active, strategic, and integral process that encompass both the measurement and the mitigation of risk, with the ultimate goal of maximizing the value of a bank, while minimizing the risk of bankruptcy (Schroeck, 2002). On other words, the proper risk management is essential for bank survival as its primary function is to ensure that the total risk being taken is matched to the bank's capacity for absorbing losses and to help the CEO direct the scarce resource of capital to the opportunities that are expected to create the maximum return with the minimum risk (Marrison, 2002).

As a result of the dynamic and volatile economic environment, many bodies (regulatory, supervisory, and reporting) are concerned with the issuance of guidelines that govern the practices of risk management. The literature shows ample regulations and perspective frameworks for enlightened risk management including Tunbull Report, The COSO Enterprise Risk Management Framework and the international standards organization's ISO (Mike \& Kaplan, 2013). In the banking industry Basel Committee on Banking Supervision (BCBS) is concerned since 1980s with ensuring the soundness and safety of the banking sector by setting an international framework for banking risk management (BCBS, 1988). It is observable that BCBS broadens and develops its framework each decade in respect of the types of risks to measured and managed effectively in order to determine the capital adequacy ratio of the bank. In 1988, Credit risk was addressed, in 1996 Market risk was added as an amendment to Basel I, (BCBS, 1996). The International Convergence of Capital Standards and Measurement issued in 2004 (Basel II) not only added a new type of risk- Operational Risk but also stated three approaches for the measurement and management of credit and operational risk (BCBS, 2004).The subprime crisis 2007-2008 and the bankruptcy of several banks as a consequences of this crisis, leads the usefulness of Basel II requirements to be susceptible, so to overcome this criticism BCBS issued new requirements (Basel III) to address the standards to be followed for the liquidity risk management and set certain criteria to improve the quality and quantity of the capital base (BCBS, 2010).

Four ideal types form the risk management mix in a given bank: Risk Silo management, Integrated Risk management, Risk and value management and Strategic Risk Management (Mike, 2008). The first type is concerned by the measurement and control of market, credit and operational risks in 'silos' across the organization, Integrated Risk management focused on developing a common denominator measure of market, credit and operational risks to aggregate their quantifiable risks into a total risk estimates, Risk and value management advocate the idea of using risk based internal capital allocations for performance measurement and control in order to enhance the shareholder value and Strategic Risk Management advocate ERM framework and as a result, risk management framework to be gradually expanded to incorporate non- quantifiable risks in addition to those can be quantified (Mike, 2005). The two latter types of risk Management practices in banks justify the importance of moving towards Enterprise wide risk management in the banking sector (Mike, 2008).

As a response to the requirement of an integrated, robust and more comprehensive approach to managing risks, ten years ago, the Committee of Sponsoring Organizations of the Tradeway Commission (COSO) issued a separate framework for the Enterprise Risk Management (ERM) (COSO, 2004). The COSO ERM framework made the ERM an independent function and not just a component of the internal control process as its first introduction in The COSO framework of internal control process (COSO, 1992). ERM is defined as a process, affected by an entity's board of directors, management and other personnel, applied in strategy setting and across the enterprise, designed to identify potential events that may affect the entity and manage risk to be within its risk appetite, to provide reasonable assurance regarding the achievement of entity objectives (COSO, 2004). ERM gains a widespread practice in the recent years, not only to ensure the effectiveness of the control process or to help in achieving goals but also as a tool of creating value. ERM helps create a comprehensive approach to anticipating, identifying, prioritizing, and managing material risks of the company (Jalal et al., 2011).ERM is a discipline, by which an organization in any industry, assess, control, exploits, finance and monitors risks from all sources for the purpose of increasing the organizations short-and long-term value to stakeholders (Mickinsey \& Co., 2013; Srivastav, 2013).

Risk Management became a vital subject in the recent years and its importance was developed rapidly during the last two decades, risk management was formalized as an overlay, an additional objective that should complement 
whatever expected return strategy the business unit has chosen (Kaplan \& Norton, 1996). One decade later, due to the turbulences took place across several economies in the world, it was clear that risk management cannot be viewed any more as additional objective, it was argued that operational, technological and environment risk measures can be included in a balanced scorecard (Kaplan \& Norton, 2004).

Literature shows that financial firms took the initiative to include risk management in the balanced scorecard (BSC) (Nagumo, 2005). The financial firm Swiss Re included in its strategy map certain objectives related to risk management two objectives in the client (Customer) perspective and three objectives are included in the internal perspective, as well as, the international banking giant Bank of Tokyo Mitsubishi (BTM) undertook a groundbreaking in its application of BSC by incorporating in the internal perspective a risk management process, this linkage is a result of BTM's goal to enhance its corporate governance (Kaplan \& Norton, 2004). However, this linkage between risks and performance evaluation by including the risk as a component, an overlay or an additional objective did not address the risk in a comprehensive way, as well as, it was not in line with some major financial scandals which resulted in the collapsing of some banks such as Barings and Daiwa banks, was a result of poor risk management (Waring \& Glending, 1998).

Due to increased risks and the severe competition, risk management was evolved to be viewed as a third leg of shareholder value creation along with revenue growth and productivity, a three -level hierarchy of risks and the risk indicator scorecard were introduced, a parallel to the strategy scorecard that Kaplan and Norton conceived two decades ago (Kaplan, 2009). Unfortunately, introducing a working example of complete actual risk scorecard was missed for the reason that the development of a risk scorecard is more conjecture and concept than actual fact, as well as, measuring and managing risks differs so substantially from measuring and managing strategy, that it may be preferable to develop a completely separate risk scorecard (Kaplan, 2009).

In 2010, Kaplan upon his comments and analysis of the consequences of the subprime crisis, concluded that there was one thing missing that has been revealed in the last four years is that there is nothing about risk assessment and risk management and the companies need a parallel scorecard to their strategy risk-a risk scorecard (Kaplan, 2010). So it is concluded that in the recent business environment, ERM cannot be applied by just linking the performance and risk evaluation, the need for a separate scorecard addressing the risk in a comprehensive way became vital and necessary.

In a unique study by (Clandro \& Lane, 2006) suggested the application of Enterprise Risk Scorecard and they indicated that a scorecard framework could be an effective risk measurement, management and communication tool. And this is assumed to be the first formal paper on risk and scorecard framework.

Banks have identified and started adapting the Enterprise Risk Management released by COSO to drive their initiatives in risk management beyond Basel norms and regulatory compliances (Srivastav, 2013). The COSO ERM framework has all the components that could help banks to stand a chance to drive business value while meeting compliance requirements (Vaiduyla \& Kavala). The COSO ERM model ,in banking, is a common risk management framework that is generally accepted by regulators external and internal auditors and banking executives (Srivastav, 2013). As a result regulatory supervision policies in many advanced countries such as the US and Japan and the supranational regulatory bodies such as the Bank for International Settlement (BIS) arefundamentally based on the COSO framework (Nagumo, 2005). So,in the recent years, banks are urged not to only comply with Basel II \& Basel III requirements but to address the other risks which are not included in Basel framework such as marketing, growth and learning.

The Authors goes beyond the boundaries of Basel requirements and inspired the essence of this unique work of Enterprise Risk Scorecard in designing the banking balanced risk scorecard BBRSC which encompass financial risks (market, credit, operational and liquidity) and non-financial risks including: internal process which represent the operational risk included in Basel framework, in addition to customer, learning and growth which represent new types of risks addressed by the banking industry.

\section{Types of Risks in Banking}

The literature shows different classifications of risks, this paper will follow the categorization applied in the balanced scorecard, as risk is categorized in four dimensions: financial, operational, customer, learning and growth.

\subsection{Financial Risks}

In the banking industry financial risks is categorized into market, credit and liquidity risks. 


\subsubsection{Market Risk}

Market risk was defined as the risk of loss in on and off-balance-sheet positions arising from movement in market prices. The risks subject to this requirement are: the risks pertaining to interest rate related instruments and equities in the trading book; foreign exchange risk and commodities risk throughout the bank (BCBS, 1996).

Interest Rate risk is the potential negative impact on the net interest income and it refers to the vulnerability of an institution's financial condition to the movement of interest rate which affects earning, value of assets, liabilities, off-balance sheet items and cash flow (Grenuing \& Baratanovic, 2009; Marrison, 2002).

Equity risk arises from adverse deviations of the mark-to-market value of the equity position.Asany decline in value will therefore result in a market loss for the corresponding period equal to the difference between the beginning and the ending mark- to- market value (Bessis, 1998; Marrison, 2002).

Foreign exchange risk is the risk of holding or taking positions in foreign currencies, including gold (BCBS, 1996). Currency risk results from changes in exchange rates and originates in mismatches between the value of assets and liabilities denominated in different currencies (Bessis, 1998).

Commodity risk is the risk of holding or taking positions in commodities, including precious metals, but excluding gold (BCBS, 1996).

The market risk can be quantified by several tools; the most common approach is the value at risk (VaR) which represents the maximum expected loss during severe adverse market fluctuations during the holding period with a certain confidence level. (Marrison, 2002). The value at risk can be calculated for the whole trading portfolio as well as for each market risk factor (interest rate Value at risk, foreign exchange value at risk, equity value at risk), or by instrument (bonds, shares...). Some other measures can be applied by the bank such as: the change in net interest income, the change inprofits from foreign exchange transactions (Bessis, 1998).

\subsubsection{Credit Risk}

Credit risk is paramount in terms of the importance in the banking industry. It was defined by Basel committee as the potential that a bank borrower or counterparty will fail to meet its obligation in accordance with agreed terms (BCBS, 1988). On other words, credit risk can be defined by the losses in the event of default of borrower, or in the deterioration of borrower credit quality or the decline in the credit standing of counterparty. Several factors affect the credit risk, but the major risk components are: probability of default (PD), loss given default (LGD) and exposure at default (EAD) (Waring \& Glenden, 1998).

There are several aspects of credit risk, the most common two: credit default risk and credit spread risk. The default risk is measured by the probability that the default occurred during a given period of time. Counterparty risk refers to the possibility that a trading counterparty will fail to pay if it loses money on a deal. Settlement risk occurs if a bank fails to settle its side of a trade (Bessis, 1998; Marrison, 2002).

Basel committee distinguish between two broad approaches;thestandardized approach which rely on the credit assessment provided by external credit rating agenciesandtheinternal rating based approach which rely on the bank's own credit assessment.In general, banks are using several tools or approaches in order to quantify the credit risk, the most common are: credit value at risk, the ratio of non-performing loans to the total portfolio, the ratio of doubtful loans provision to the total portfolio (Bessis, 1998; Crouhy et al., 2005).

\subsubsection{Liquidity Risk}

Liquidity Risk was defined as the risks that demands for repayment outstrip the capacity to raise new liabilities or liquefy assets (BCBS, 2001). An evaluation of whether or not a bank is sufficiently liquid depends on the behavior of cash flows under different conditions. Accordingly, for the proper liquidity risk management, the ability to readily convert assets into cash and access to other sources of funding in the event of liquidity shortage are very important (Crouhy et al., 2005). Liquidity risk management must therefore involve various scenarios: the going concern (ordinary scenario), bank's liquidity crisis situation and general market crisis (Grenuing \& Baratanovic, 2009).

The Basel committee introduced a global liquidity standard that includes a 30-day liquidity processing (liquidity Coverage Ratio) requirement underpinned by a longer-term structural liquidity ratio (Net Stable Fund Ratio) (BCBS, 2010). However the Egyptian banks are not applying the two ratios required by Basel III till the present time. Egyptian banks are relying on the traditional liquidity ratio analysis in analyzing the liquidity risk faced by the bank. The most common liquidity ratios include: the ratio of liquid assets to deposits and stable funding, the ratio of net loans to total assets and the ratio net loans to deposits and stable funding.

The following table summarizes the main financial risk measures. 
Table 1. Financial risk measures

\begin{tabular}{ll}
\hline Risk & \multicolumn{1}{c}{ Measures } \\
\hline MarketRisk & Value at Risk (totalVaR, IR VaR, F.X VaR). \\
& Change in net interest income \\
& Change in profits from foreign exchange transactions. \\
& Change in trading shares market value. \\
& Credit Value at risk \\
& \% Nonperforming loans to credit portfolio \\
Credit Risk & \% Loans Provision to credit portfolio \\
& liquid assets /deposits and stable funding \\
& Net loans/ total assets \\
Liquidity risk & Net loans/ deposits and stable funding \\
&
\end{tabular}

\subsection{Operational Risk}

Operational Risk was defined as the risk of direct or indirect loss resulting from inadequate or failed internal processes, people and systems or from external events (BCBS, 2001). Following severe operational failures which affected a number of financial institutions such as: Natwest, Allied Irish Bank and LTCM the importance and the emphasis of operational risk within banks are increased (Helbok \& Wanger, 2006). Operational risk can be viewed as the risk associated with the problems of accurately processing, settling and taking or making delivery on trades in exchange of cash (Santomero, 1997).

Basel committee provide Detailed three level Classification of theLoss Events which expose the bank to operational losses (Internal fraud, External fraud, Employment Practices and Workplace Safety, Clients, Products \& Business Practices, Damage to Physical Assets, Business disruption and system failures and Execution \& Delivery Process Management (BCBS, 2004).

Basel II sets three approaches for calculating the capital charge of the operational risk: Basic indicator approach (BIA), Standardized Approach(SA), and the advanced measurement approach (AMA). According to BIA the operational risk capital charge is equals to $15 \%$ of average gross income over three years, SA is not so different from BIA, instead of the gross income of the whole bank, the average gross income of each business line as identified by Basel committee is multiplied by risk factor, ranging from $12 \%$ to $18 \%$, assigned for each business line (12\%-18\%), the third approach, AMA, relies on using the risk factors related to operational risk : probability of event PE, loss given Event LGE, and the exposure indicator EI in calculating the operational value at risk (Marrison, 2002).

Table 2. Operational risk measures

\begin{tabular}{ll}
\hline Risk & Measures \\
\hline OperationalRisk & Operational Value at Risk \\
& $15 \%$ Average Gross Income \\
& Ratio of operation risk provision to operating income \\
\hline
\end{tabular}

Learning and Progress Perspective.

The capability of bank to progress and learning that represent as direct ties with firm's value thereforetheinnovation and learning objectives are intended to drive improvement in financial, customer and internal process performance (Kaplan \& Norton, 1993).

The innovationand learning objectives should be linking with bank'sstrategywhichdetermined by boardof directors to translatethemaximumacceptable level of risk in light of their knowledge about market and return risks (Woods, 2008) that expressed as risk appetite of bank.

This strategy set hypothesesabout cause and effect that can be expressed by sequence of IF-Then statements (Kaplan \& Norton, 1996), howeverthe increase ofemployee's awareness of risk causesincrease in effectivenessof risk management and in the same time the progress of employee awareness of risk result from increasing of employee training about risk technique and tools.

In light of the link between cause and effect bank can be able to set objectives of progress and learning risk perspectives that reflect its strategy. 
The effectiveness of achievement these objects should be measured by Common measurements includinga bank's ability to innovate, improve, and learn that classify as follows:

Table 3. Learning \& growth risk measures

\begin{tabular}{ll}
\hline Risk & Measures \\
\hline Learning & Risk Training Hours per employee compared with \\
Increase employee awareness of risk management. & bank leader in market. \\
$\underline{\text { Progress }}$ & The progress of Risk adjusted return measure. \\
$\begin{array}{l}\text { Increase the employee'scapabilityin define, measure and monitoringrisk by } \\
\text { achievingthe highest profitability and acceptable risk }\end{array}$ & \\
\hline
\end{tabular}

\subsection{Customer Risk Perspective}

Customer risk pertains to the risk of bank's overall portfolio of customers. The risk of losing these customers can be measured in several ways (Clandro \& Lane, 2006). It has become increasingly important to view customers as risky assets (Hogan et al., 2002), because the firm's life existence and value is a function of its ability to satisfy their customers' needs and desires (Calandro \& Scott, 2006) in the light of customer asset management perspective that may generate cash flow consistently over time.

The valuable of customer asset including the acquisition, retention, developing and deletion costs (Blatberg et al., 2001).

The sources of risk pertain to the risk of banks overall portfolio of customers can be classified into a Varity of factors such as follows:

Table 4. Customer risk measures

\begin{tabular}{ll}
\hline \multicolumn{1}{c}{ Risk } & \multicolumn{1}{c}{ Measures } \\
\hline Customer defection & Decreasing Customer Base \\
& Decreasing loan's portfolio \\
& Decreasing deposit's portfolio \\
& Increasing the percentage of provision comparison to increasing the percentage of loan's portfolio \\
Poor customer quality & Stability of customer base comparison to increasing customer base of competitors \\
Customer acquisition &
\end{tabular}

\section{Research Problem}

Kaplan (2010) state that firms need a parallel scorecard to their strategy scorecard- a risk scorecard and it was one thing missing that has been revealed in the last few years.

The risks are categorized into: financial and non-financial risks (Srivastav, 2013). In other words the portfolio of risk balanced scorecard includes objective and subjective elements (Collier et al., 2007). Recognizing this risks and managing them appropriately enhance the ability of the firm to make better decisions, delivers bank's objectives and hence subsequently improve performance (Jalal, 2011), so banks invested a significant amount of money in risk management programs, However it is questionable if these programs do really pay off for them, in the same time the literature doesn't supply enough information about the role of (BRBS) in adding value to banks, also the effectiveness of (BRBS) still remains untested because of lack of suitable framework and techniques.

The research question is: Does the adoption of Banking risk balanced scorecard that consists of financial and non financial risk measures lead to enhance both of bank's competitive advantage and stakeholder value? This paper provides evidence on effectiveness of this issue.

\section{Research Objectives}

This research aims to achieve the following objectives:

- Measuring the effectiveness of Banking Wide Risk Scorecard,

- Identifying the other value driver of the banks,

- Developing a conceptual framework of measuring the benefits of (BRBS). 


\section{Methodology}

In addition to providing dimensions of (BRBS) framework and its measures to maximize Bank value, we decompose Economic value add to measure the benefit of shareholder value and Tobin's $Q$ to measure the benefit of other stakeholder value, while using Market share indicator as a proxy of measuring competitive advantage.

\subsection{Market-Based Measures}

There are many based measures that can be used to explain and manipulate market capitalization or shareholder value (Srivastava et al., 1998). previous studies had widely used Economic value added (EVA), Market Value Added (MVA) and Tobin's Q which are widely accepted as reliable and strong measures in additional reflect future or long term of firm economic value (Chen, 2010), one that is forward looking cumulative (Anderson et al., 2004), change/flow measures (Hogan et al., 2002).

The authors use the following measures of bank value.

\subsubsection{Economic Value Added (EVA)}

Economic value added is an operating profit after taxes less a charge for capital equal to the product of capital and its cost.

$\mathrm{EVA}=$ net operating profit after tax (NOPAT)-(capital $\mathrm{x}$ the cost of capital) (Hogan et al., 2002).

EVA is closely related to MVA - the difference between the market value of the firm and the economic value of the capital it employs. The Increased interest in EVA and related performance measures reflects a heightened awareness by corporate managers that their task is to create 0value for shareholders (Lhen \& Makhija, 1996).

EVA can be created in four ways: by enhancing operating efficiency, asset management, 09increasing profitability growth and by reducing the cost of capital (Lilley et al., 2008).

Firm level risk management can increase shareholder value by facilitating investor-based risk management. In the same time industries which are rapidly evolving and changing, and which have few tangible assets might also be good candidates for risk exposure targeting (Meulbroek, 2002).

The main objective faces the managers in firm who seeks to implement risk management is to reduce earning fluctuations or to reduce fluctuation in firm value (Welssenriden, 1997). So the fundamental goal of risk management is maximizing shareholder and firm value.

Following this reasoning we state the following mean hypothesis.

H1: the greater the ability of a bank to manage (BRBS), the greater its Economic value added.

We estimated EVA efficiency by postulating a relationship among EVA and BRBS. This relationship is summarized in the EVA function for a given bank of time $t$ (Equation 1), which models the logarithm of a bank's EVA where $\mathrm{EVA}_{\mathrm{iT}}$ as a linear function of the logarithms of variable input.

$$
\begin{gathered}
\operatorname{Ln}\left(E V A_{i T}+\Delta\right)=F\left(\operatorname{LnEVA}_{i T-1}, \operatorname{LnMr}_{i T}, \operatorname{LnCr}_{i T}, \operatorname{LnLQ}_{i T}, \operatorname{LnIr}_{i T}, \operatorname{LnLgr}_{i T},\right. \\
\left.\operatorname{LnGr}_{i T}, \operatorname{LnCdr}_{i T}, \operatorname{LnCpr}_{i T}, \operatorname{LnCAr}_{i T}, \operatorname{Ln} \lambda_{i T-1}, \operatorname{Lnu}_{i T}^{v}\right)
\end{gathered}
$$

Where $\operatorname{Ln}\left(\mathrm{EVA}_{\mathrm{iT}}+\Delta\right)$ is economic value added we add a constant, $\Delta$, to EVA of all banks to ensure that the values are positive (Kirasnikov et al., 2009). LnEVA $_{\mathrm{iT}-1}$ refers to one- year lagged value of economic value added $(\mathrm{x} 1), \mathrm{Mr}_{\mathrm{iT}}$ refers to the market risk(x2), $\mathrm{Cr}_{\mathrm{iT}}$ refers to credit risk(x3), $\mathrm{LQ}_{\mathrm{iT}}$ refers to liquidity $\operatorname{risk}(\mathrm{x} 4), \mathrm{Ir}_{\mathrm{iT}}$ refers to internal risk(x5), $\operatorname{Lg}_{\text {iT }}$ refers to learning $\operatorname{risk}(\mathrm{x} 6), \mathrm{Gr}_{\mathrm{iT}}$ refers to growth $\operatorname{risk}(\mathrm{x} 7), \mathrm{LnCdr}_{\mathrm{iT}}$ refers to customer defection(x8), $\operatorname{LnCpr}_{\mathrm{iT}}$ refers to poor banks portfolio of clients(x9), $\operatorname{LnCAr}_{\mathrm{iT}}$ refers to customer acquisition(x10), $\lambda \mathrm{i}_{\mathrm{T}-1}$ refers to economic condition by using 90-day Egy. Treasury bills interest rate(x11).

We estimated equation 1 for every time period ${ }_{\mathrm{T}}$ over a five year period which include twenty quarterbalance sheetconcerning 3 Egyptian commercial banksto capture efficiency, as the first step, we completed a time series of residuals for every bank (Kirasnikov et al., 2009).

Banks with higher residuals from the EVA function demonstrated superior EVA because they earn higher EVA than an average bank (Barger et al., 1993); we measured EVA efficiency as the distance between the EVA of the focal bank and that of the most EVA bank in the sample. As such, EVA efficiency is the difference between the maximum residual obtained from fitting the EVA function of and the residual for the focal bank. Therefore, higher values of $\mathrm{EVA}_{\mathrm{iT}}$ correspond to lower values of EVA efficiency:

$$
E V A E F_{i T}=E X P\left(\operatorname{Lnu}^{v} \max -\operatorname{Lnu}^{v}{ }_{i T}\right)
$$

Measures of variables we measured $\mathrm{Mr}_{\mathrm{iT}}$ using value at risk, $\mathrm{Cr}_{\mathrm{iT}}$ using credit value at risk and $\mathrm{LQ}_{\mathrm{iT}}$ using $\mathrm{Net}$ 
loans/ Total assets we measured internal risk $\operatorname{Ir}_{\mathrm{iT}}$ using $15 \%$ average gross income. We measured learning $\operatorname{Lgr}_{\mathrm{iT}}$ using risk training hours per employee and progress $\mathrm{Gr}_{\text {iт }}$ using the progress of risk adjusted return measure.

We measured customers as risky assets by accessing the relevant information from Egyptian Central Bank, personal visits, telephone conversation with marketing executives. We created two groups of banks after reviewing all the information: Banks with high:

$\mathrm{Cd}_{\mathrm{iT}}=1$ and low $\mathrm{Cd}_{\mathrm{iT}}=0$ degree of customer defection.

$\mathrm{Cd}_{\mathrm{iT}}=1$ and low $\mathrm{Cd}_{\mathrm{iT}}=0$ degree of poor bank's portfolio of clients.

$\mathrm{Cd}_{\mathrm{iT}}=1$ and low $\mathrm{Cd}_{\mathrm{iT}}=0$ degree of customer acquisition.

$$
\mathrm{Z}=F\left[\sum_{\mathrm{j}=1}^{\mathrm{j}} \mathrm{W}_{\mathrm{j}}{ }^{(2)} \mathrm{F}_{\mathrm{j}}\left(\sum^{\mathrm{i}}{ }_{\mathrm{i}=1} \mathrm{~W}_{\mathrm{ij}}{ }^{(1)} \mathrm{X}_{\mathrm{i}}\right)\right]
$$

$\mathrm{Z}=$ multilayer perception (MLP) outputs $\left(\mathrm{EVAEF}_{\mathrm{iT}}\right)$;

$\mathrm{F}=$ the transfer function in the output layer;

$\mathrm{W}_{\mathrm{ij}}$ and $\mathrm{W}_{\mathrm{i}}=$ connection weights from input layer (i) to hidden layer ( $\mathrm{j}$ ) to output layer respectively.

$\mathrm{Xi}=$ is the inputs (eleven variables as mentioned above).

\subsubsection{Tobin's Q}

Is the ratio of the market value of the firm to the replacement cost of each tangible asset.

It considers an intangible firm value measure (Lu et al., 2010). A Q value greater than one indicates that the bank has intangibleassets. it enables a firm to create earnings in excess of the return of its tangible assets and to achieve an abnormal return on invested capital relative to its competitors (Hogan et al., 2002), using its resources more effectively (Anderson et al., 2004), creates value for its share holder (Matzelar et al., 2005).

A firm that doesn't create incremental value has A Tobin s Q equal to one .According to prior literature (Anderson et al., 2004; Lu et al., 2010) there are practical problems associated with implementing the previousdefinition so according to manyprior researches (Lu et al., 2010; Matzelar et al., 2010), suggest modifying function to be come as following:

$$
Q=\text { Market value of equity }+ \text { book value of debt / total assets }
$$

In this paper, the $\mathrm{Q}$ is dummy variable,taking 1 if the ratio is more than 1 which means a firm owns higher intangible firm value, otherwiseis0 .

Lastly the literature (Archary \& Mutenga, 2013; Hyot, 2011) Found positive relationship between implementing ERM and firm value. However the authors believe that the insurance sector deferent from banking sector and this will reflect on design a Banking risk balanced scorecard framework (BRBS), to evaluate the add value by (BRBS).

Following this reasoning we state the following mean hypothesis.

H2: the greater the ability of a bank to manage (BRBS), the greater the possibility that Tobin's Q will be more than one.

As we noted previously, T'sQEF ${ }_{\text {iT }}$ has the form that is similar to that of the $\mathrm{EVAEF}_{\mathrm{iT}}$, as the following:

$$
\begin{aligned}
& L n T \text { 's } Q_{i T}=F \text { (T's } Q_{i T-1}, L n M r_{i T}, L n C r_{i T}, L n L Q_{i T}, \operatorname{LnIr}_{i T}, \operatorname{LnLgr}_{i T}, \operatorname{LnGr}_{i T}, \operatorname{LnCdr}_{i T} \text {, } \\
& \left.\operatorname{LnCpr}_{i T}, \operatorname{LnCAr}_{i T}, \operatorname{Ln} \lambda_{i T-1}, \operatorname{Ln} u_{i T}^{v}\right) \\
& \text { T's QEFiT }=\text { EXP }\left(\text { Lnu }^{v} \max -\operatorname{Lnu}_{i T}^{v}\right) \\
& \mathrm{Z}=F\left[\sum_{\mathrm{j}=1}^{\mathrm{j}} \mathrm{W}_{\mathrm{j}}{ }^{(2)} \mathrm{F}_{\mathrm{j}}\left(\sum^{\mathrm{i}}{ }_{\mathrm{i}=1} \mathrm{~W}_{\mathrm{ij}}{ }^{(1)} \mathrm{X}_{\mathrm{i}}\right)\right]
\end{aligned}
$$

Where:

$\mathrm{Z}=$ multilayer perception (MLP) outputs (T's $\left.\mathrm{QEF}_{\mathrm{iT}}\right)$;

$\mathrm{F}=$ the transfer function in the output layer;

$\mathrm{W}_{\mathrm{ij}}$ and $\mathrm{W}_{\mathrm{i}}=$ connection weights from input layer (i) to hidden layer ${ }^{(j)}$ to output layer respectively.

$\mathrm{Xi}=$ is the inputs (eleven variables as mentioned above).

\subsubsection{Market Share}

Firms sales don't indicate how will is performing versus its reviles; so management needs to track its market share (Kotler, 2004) which can be measured throw a firm's sales in relation to full industry sales for a certain period. 
Market share is a key indicator of market competitive advantage it indicates firms transient probabilities against its reviles. it enables management to judge not only total market growth or decline but Also trends in customers 'selections among reviles (Siggle, 2007) also the change in market share can be taken as dynamic indicator of competitive advantage.

The main advantage of using market share as a measure of competitive advantage or business performance it is dependent on micro-environmental variables rather than macro environmental variables, micro economic concept indicators of competitive advantage have a more solid theoretical base because they focus on the essential characteristic of producers in competition for market share and the profits or the ability to export this ability could be measured by the size or increase of market share.

Lastly the literature indicates that competitive advantage in the second key benefit-the other is shareholder valueof enterprise risk management (Ashary, 2008) and the authors adopt market share as a proxy of competitive advantage.

Following this reasoning we state the following mean hypothesis.

H3: the greater the ability of a bank to manage (BRBS), the greater its competitive advantage.

As we noted previously, T'sQEF ${ }_{\mathrm{iT}}$ has the form that is similar to that of the $\mathrm{Ln} \mathrm{MSHEF}_{\mathrm{iT}}$, as the following:

$$
\begin{aligned}
& \operatorname{LnMSH}_{i T}=F\left(\mathrm{LnMSH}_{i T-1}, \operatorname{LnMr}_{i T}, \operatorname{LnCr}_{i T}, \operatorname{LnLQ}_{i T}, \operatorname{LnIr}_{i T}, \operatorname{LnLgr}_{i T}, \operatorname{LnGr}_{i T}\right. \text {, } \\
& \left.L n C d r_{i T}, \operatorname{LnCpr}_{i T}, \operatorname{LnCAr}_{i T}, \operatorname{Ln}_{i T-1}, \operatorname{Lnu}_{i T}^{v}\right) \\
& \operatorname{LnMSHEF}_{i T}=\operatorname{EXP}\left(\operatorname{Lnu}^{v} \max -\operatorname{Lnu}_{i T}^{v}\right) \\
& Z=F\left[\sum_{\mathrm{j}=1}^{\mathrm{j}} \mathrm{W}_{\mathrm{j}}{ }^{(2)} \mathrm{F}_{\mathrm{j}}\left(\sum_{\mathrm{i}=1}^{\mathrm{i}} \mathrm{W}_{\mathrm{ij}}{ }^{(1)} \mathrm{X}_{\mathrm{i}}\right)\right]
\end{aligned}
$$

Where:

$\mathrm{Z}=$ multilayer perception (MLP) outputs $\left(\mathrm{LnMSHEF}_{\mathrm{iT}}\right)$;

$\mathrm{F}=$ the transfer function in the output layer;

$\mathrm{W}_{\mathrm{ij}}$ and $\mathrm{W}_{\mathrm{i}}=$ connection weights from input layer (i) to hidden layer (j) to output layer respectively.

$\mathrm{Xi}=$ is the inputs (eleven variables as mentioned above).

\section{Artificial Neural Networks}

Inspired by the previous research, the study uses a neural network based on a multilayer perception (MLP). MLP is a feed- forward back- propagation that utilizes a supervised learning algorithm and widely employed in the management science.

The calculation of the MLP weights is known as training process (Wang, 2005). MLP is trained by the backproagation learning algorithm. The purpose of the training is to permit the MLP to learn some general features that may exist in the training set and to find the weights that minimize the overall error measure. This process is done by adjusting the connection weights by propagating the error backward through the network to determine how to best update the interconnection weights between neurons. Once adequately trained, the network will be capable of predicting patterns from the testing data set that were independent of the training data set (Detienne et al., 2003).

Unlike statistical methods, artificial neural networks (ANNs) models don't make dependency assumptions among input variables and solve multivariate problem with nonlinear relationship among variables (Binli 2002).In other words, NNs have the ability to make it possible to forgo strict statistical assumptions and specifications problems, and to process data by means of a flexible statistical tool.

\subsection{Results from Artificial Neural Networks}

Neural MLP has run eleven inputs 11 independent variables, 3 coded and 8 numerical also, neural MLP has run 3 dependent variables (EVA, T's Q, MSH). The statistical parameters of significance generated by SPSS22 at the end of the training and testing calculation, to evaluate the performance and effectiveness of the neural network, are presented in table 1 and are explained as follows:

Relative Error: is the preceptor values of the error and predicted values (Mahbub et al., 2013). The lower the relative error is, the better the accuracy of the model.

SSE sum squared error and its statistical measures of the difference between the actual and predicted outputs. The lower the value of these errors, the better is the performance of the neural network, and vice versa as regards 
the first hypothesis, data analysis is shown in Table 1:

Table 1. Statistical parameters of significance generated of EVA by MLP in three banks

\begin{tabular}{lcccccc}
\hline Bank & \multicolumn{2}{c}{ CIB } & \multicolumn{2}{c}{ ALEX } & \multicolumn{2}{c}{ UNBE } \\
IV & Importance & $\begin{array}{c}\text { Normalized } \\
\text { Importance }\end{array}$ & Importance & $\begin{array}{r}\text { Normalized } \\
\text { Importance }\end{array}$ & $\begin{array}{c}\text { Importance } \\
\text { Importance }\end{array}$ \\
\hline LnCd & 0.051 & $28.70 \%$ & 0.1 & $61.50 \%$ & 0.108 & $71.70 \%$ \\
LnCp & 0.056 & $31.70 \%$ & 0.053 & $32.70 \%$ & 0.084 & $56.10 \%$ \\
LnCA & 0.045 & $25.30 \%$ & 0.026 & $15.90 \%$ & 0.097 & $64.60 \%$ \\
LnEVA iT-1 $_{\text {LnMr }}$ & 0.123 & $69.10 \%$ & 0.087 & $53.30 \%$ & 0.15 & $100.00 \%$ \\
LnCr & 0.099 & $55.70 \%$ & 0.104 & $63.60 \%$ & 0.067 & $44.70 \%$ \\
LnLQ & 0.058 & $32.50 \%$ & 0.124 & $76.10 \%$ & 0.075 & $49.70 \%$ \\
LnIr & 0.104 & $58.30 \%$ & 0.163 & $100.00 \%$ & 0.073 & $48.50 \%$ \\
LnLg & 0.079 & $44.20 \%$ & 0.079 & $48.10 \%$ & 0.126 & $83.50 \%$ \\
LnGr & 0.115 & $64.40 \%$ & 0.057 & $34.90 \%$ & 0.053 & $35.50 \%$ \\
Ln $1_{i T-1}$ & 0.093 & $52.30 \%$ & 0.093 & $56.70 \%$ & 0.042 & $28.00 \%$ \\
Relative Error & 0.178 & $100.00 \%$ & 0.114 & $69.50 \%$ & 0.124 & $82.60 \%$ \\
Sum squared error & & 0.001 & & 0.001 & & 0.001 \\
\hline
\end{tabular}

Table 1 refers to the relative importance of the variables that affect the effectiveness of economic value added and its relative weights according to the outputs of the network training process. The variables with normalized importance greater than $50 \%$ for CIB are: economic conditions, one-year lagged economic value added, learning risk, liquidity risk, and growth risk. The variables For ALEX are: liquidity risk, credit risk, economic conditions, market risk, customer defection, and growth risk. The variables For UNBE are:one-year lagged economic value added, internal risk, economic conditions, customer defection, and poor bank's portfolio of clients.

The above mentioned statistical analysis shows the following implications:

- Economic conditions have the greatest impact on EVA, as it represents a common variable in the three banks. This conclusion is meaningful as a consequence of the international financial crisis which took place in 2008 and reflected on different countries around the world, as well as, the political turbulences in Egypt that hasaffected the economic environment since 2011 up till now.

- Customer risk has a great effect on EVA in both of UNBE (customer defection, poor bank's portfolio of clients) \&ALEX bank (customer defection). This result appears as a significant indicator to the importance of including intellectual capital (represented in customeras risky asset component) in the BRBS matrix. This conclusion makes this research to go beyond the boundaries of Basel requirements which addresses the financial risk only.

Concerning the second hypothesis, data analysis is shown in Table 2:

Table 2. Statistical parameters of significance generated of TQ by MLP in three banks

\begin{tabular}{lcccccc}
\hline Bank & \multicolumn{2}{c}{ CIB } & \multicolumn{2}{c}{ ALEX } & \multicolumn{2}{c}{ UNBE } \\
\hline IV & Importance & $\begin{array}{c}\text { Normalized } \\
\text { Importance }\end{array}$ & Importance & $\begin{array}{c}\text { Normalized } \\
\text { Importance }\end{array}$ & $\begin{array}{c}\text { Importance } \\
\text { Importance }\end{array}$ \\
\hline LnCd & 0.006 & $2.20 \%$ & 0.087 & $41.30 \%$ & 0.043 & $27.70 \%$ \\
LnCp & 0.024 & $8.70 \%$ & 0.033 & $15.60 \%$ & 0.068 & $43.30 \%$ \\
LnCA & 0.024 & $8.70 \%$ & 0.056 & $26.50 \%$ & 0.074 & $47.40 \%$ \\
LnEVA & 0.026 & $9.70 \%$ & 0.085 & $40.00 \%$ & 0.118 & $75.60 \%$ \\
LnMr & 0.272 & $100.00 \%$ & 0.089 & $41.90 \%$ & 0.12 & $76.70 \%$ \\
LnCr & 0.111 & $40.70 \%$ & 0.096 & $45.30 \%$ & 0.072 & $46.30 \%$ \\
LnLQ & 0.233 & $85.70 \%$ & 0.212 & $100.00 \%$ & 0.156 & $100.00 \%$ \\
LnIr & 0.043 & $15.70 \%$ & 0.065 & $30.70 \%$ & 0.091 & $58.30 \%$ \\
LnLg & 0.026 & $9.40 \%$ & 0.072 & $34.20 \%$ & 0.009 & $5.60 \%$ \\
LnGr & 0.081 & $29.80 \%$ & 0.093 & $43.70 \%$ & 0.117 & $74.70 \%$ \\
\hline
\end{tabular}




\begin{tabular}{|c|c|c|c|c|c|c|}
\hline $\operatorname{Ln} \lambda_{\mathrm{iT}-1}$ & 0.155 & $57.00 \%$ & 0.113 & $53.20 \%$ & 0.133 & $84.90 \%$ \\
\hline Relative Error & \multicolumn{2}{|c|}{0.019} & \multicolumn{2}{|c|}{0.007} & \multicolumn{2}{|c|}{0.007} \\
\hline Sum squared error & \multicolumn{2}{|c|}{0.033} & \multicolumn{2}{|c|}{0.001} & \multicolumn{2}{|c|}{0.001} \\
\hline
\end{tabular}

Table 2 refers to the relative importance of the variables that affect the effectiveness of Tobin's Q and its relative weights according to the outputs of the neural network. The variables with normalized importance greater than $50 \%$ for CIB are: market risk, liquidity risk, and economic conditions. The variables For ALEX are: liquidity risk and economic conditions. The variables For UNBE are: liquidity risk, economic conditions, market risk, :one-year lagged Tobin's Q, growth risk and internal risk.

The above mentioned statistical analysis shows the following implications:

- Almost all the variables which affect on the three banks are identical approximately, which refers to the need to pay for these variables a particular importance to be reflected on the Tobin's Q positively.

- Liquidity risk and the economic conditions share the greatest impact on Tobin's Q, as they represent common variables in the three banks. This conclusion is meaningful in severe economic conditions. In the meantime, market risk comes in the second rank as they are shown in two banks.

Concerning the third Hypothesis, data analysis is shown in Table 3:

Table 3. The statistical parameters of significance generated of MS by MLP in three banks

\begin{tabular}{lcccccc}
\hline Bank & \multicolumn{2}{c}{ CIB } & \multicolumn{2}{c}{ ALEX } & \multicolumn{2}{c}{ UNBE } \\
\hline IV & Importance & $\begin{array}{r}\text { Normalized } \\
\text { Importance }\end{array}$ & Importance & $\begin{array}{r}\text { Normalized } \\
\text { Importance }\end{array}$ & $\begin{array}{c}\text { Importance } \\
\text { Normalized } \\
\text { Importance }\end{array}$ \\
\hline LnCd & 0.029 & $16.10 \%$ & 0.066 & $38.10 \%$ & 0.027 & $17.90 \%$ \\
LnCp & 0.053 & $29.50 \%$ & 0.038 & $22.20 \%$ & 0.058 & $38.20 \%$ \\
LnCA & 0.048 & $26.60 \%$ & 0.03 & $17.40 \%$ & 0.128 & $84.60 \%$ \\
LnEVA iT-1 $_{\text {LnMr }}$ & 0.041 & $22.60 \%$ & 0.172 & $100.00 \%$ & 0.032 & $21.10 \%$ \\
LnCr & 0.18 & $100.00 \%$ & 0.063 & $36.50 \%$ & 0.135 & $89.20 \%$ \\
LnLQ & 0.048 & $26.80 \%$ & 0.073 & $42.10 \%$ & 0.098 & $65.00 \%$ \\
LnIr & 0.152 & $84.60 \%$ & 0.13 & $75.40 \%$ & 0.075 & $49.70 \%$ \\
LnLg & 0.116 & $64.40 \%$ & 0.099 & $57.70 \%$ & 0.151 & $100.00 \%$ \\
LnGr & 0.073 & $40.80 \%$ & 0.027 & $15.90 \%$ & 0.092 & $60.80 \%$ \\
Ln $\lambda_{\text {iT-1 }}$ & 0.151 & $83.90 \%$ & 0.156 & $90.70 \%$ & 0.1 & $65.90 \%$ \\
Relative Error & 0.111 & $61.90 \%$ & 0.145 & $84.20 \%$ & 0.105 & $69.40 \%$ \\
Sum squared error & & 0.001 & & 0.001 & & \\
\hline
\end{tabular}

Table 3 refers to the relative importance of the variables that affect the effectiveness of Market Share and its relative weights according to the outputs of the neural network. The variables with normalized importance greater than 50\% for CIB are: market risk, liquidity risk, Growth risk, internal risk and economic conditions. The variables For ALEX are: one-year lagged market share, growth risk, economic conditions, liquidity risk and internal risk. The variables For UNBE are: internal risk, market risk, customer defection, economic conditions, growth risk, learning risk and credit risk.

The above mentioned statistical analysis shows the following implications:

- It is worth to mention that the effect of customer as risky assets component did not appear except in UNBE bank through its sub- variable customer defection. This particularly may be explained due to the reason that UNBE is the smallest one in both of size and market share, which make it more sensitive compared to CIB \& ALEX. Furthermore, CIB doesn't concentrate on market share but on more profitable segments, while ALEX bank has a wide customer base because of being one of the public banks before it has been acquired by Intesa San Paolo group.

- Liquidity riskis shown in two banks; this result gives the implication that liquidity problems can affect the market share of the bank.

- Internal risk plays a crucial role in the market share of the bank, as internal risk refers to the failure of operating and control system, which in turn have negative impact on the clientele base of the bank. 
- Economic conditions represents an important factor in determining the market share of the bank , as the greater the bank suffer from the adverse economic condition, the greater its market share declines.

\section{Conclusion \& Recommendations}

The Central premise of this article is that the effectiveness of implementing of banking risk balanced scorecard has a critical role in enhancing bank value, so the objective of our study was to explore the effectiveness of BRBS on three market based measures as proxy for firm value.

Our approach provides initial evidence on the value relevance of BRBS in banking industries.

We have developed a conceptual framework for measuring the impact of Banking risk balanced scorecard which come from several areas that rely on both of objectivity \& subjectivity phenomena, financial, marketing and management theories and areas through and beyond Basel requirements. However it is challenging to link and integrate these several levels of philosophical understanding into a common framework (Acharyya, 2008).

Our approach is different from much existing research related to enterprise risk management because it:

1) Focuses on the banking universe where the risks are multi-dimensional through and beyond Basel requirements.

2) Focuses mostly on quantitative measures for both of stakeholders (shareholder value \& intellectual capital) through EVA \& Tobin's Q measures while covering competitive advantage through market share.

3) Takes into consideration tow conditions of efficient frontier which maximize expected return and minimize risk for varying levels of expected return (Sharp et al., 1995) where value cannot be created without sustainable risk taking (Acharyya, 2008).

We have found that banking risk Balance score card has a positive effect on both the economic value added \& Tobin's Q, hence the results support the notion that BRBS has an essential role to maximize shareholders value and intellectual capital, in the meantime findings assumed that banks successful BRBS practice demonstrates their superior market share, hence it has had a significant impact on a competitive advantage.

On the whole, the results show that BRBS enhances the effectiveness of Bank value.

\section{Future Research \& Limitations}

To our knowledge, our study is the first one in this direction specially to document the value relevance of BRBS but there are several avenues and a lot of efforts for further research as well as limitations that should be discussed ,hence replicated studies should be done in other different environments in addition to verify the findings and to lead to accumulate knowledge, in the meantime the model did not include all the variables which included in the matrix of BRBS due to the absence and the difficulty of obtaining the requireddata to run the model and here comes the importance of applying the model in different countries that can provide missing data.

\section{References}

Basel Committee on Banking Supervision (BCBS). (1988). International convergence of capital measurement and capital standards. Basel Publications, 1-26. Retrieved from http://www.bis.org/publ/bcbs04a.htm

Basel Committee on Banking Supervision (BCBS). (1996). The amendment to the capital accord to incorporate market risks. Basel Publications, 1-56. Retrieved from http://www.bis.org/publ/bcbs24.pdf

Basel Committee on Banking Supervision (BCBS). (2001). Risk management practices and regulatory capital: Cross- sectorial comparison. Basel Publications, 1-126. Retrieved from http://www.bis.org/publ/joint04.pdf

Basel Committee on Banking Supervision (BCBS). (2001). Sound practices for the management and supervision of operational risk. Basel Publications, 1-26. Retrieved from http://www.bis.org/publ/bcbs86.htm

Basel Committee on Banking Supervision (BCBS). (2004). International framework of capital measurement and capital standards: A revised framework. Basel Publications, 140-152. Retrieved from http://www.bis.org/publ/bcbs107.htm

Basel Committee on Banking Supervision (BCBS). (2010). International framework for liquidity measurement, standards and monitoring. Basel Publications, 1-53. Retrieved from http://www.bis.org/publ/bcbs188.pdf

Berger, D. H., \& David, H. (1993). Bank Efficiency Derived from the profit Function. Journal of Banking and Finance, 17(2-3), 317-347. http://dx.doi.org/10.1016/0378-4266(93)90035-C

Bessis, J. (1998). Risk Management in Banking. London: John Wiley \& Sons LTD. 
Bin, L. (2002). Spatial interpolation of weather variables using artificial neural network.

Calandro, J. R. J., \& Lane, S. (2006). An introduction to the enterprise risk scorecard. Measuring Business Excellence, 10(3), 31-40. http://dx.doi.org/10.1108/13683040610685775

Collier, P. M., \& Gaye, A. (2005). Management Accounting: Risk and Control Strategy. Oxford: Elsevier.

Collier, P. M., Berry, A. J., \& Bruke, G. T. (2007). Risk and management accounting: Best practices for enterprise-wide international procedures. Oxford: CIMA publishing.

Committee of Sponsoring Organizations of the Tradway Commission (COSO). (1992). Internal Control Integrated Framework. Coso Publications, 1-163. Retrieved from http://www.coso.org/.../internal\%20control-integrated\%20framework.pdf

Committee of Sponsoring Organizations of the Tradway Commission (COSO). (2004). Risk Management Integrated Framework. Coso Publications, 1-16. $\quad$ Retrieved from http://www.coso.org/erm-integratedframework.htm

Crouhy, M., Galai, D., \& Robert, M. (2005). The Essentials of Risk Management. New York: McGraw-Hill.

Detienne, K. B., Detienne, D. H., \& Joshi, S. A. (2003). Neural networks as statistical tools for business researchers. Organizational $\quad$ Research $\quad$ Methods, $236-265$. http://dx.doi.org/10.1177/1094428103251907

Fayol, H. (1916). Management Administration Industrielleet Generale.

Gallagher, R. (1956). Risk management: A new phase of cost control. Harvard Business Review-Boston, 34(5), 75-86.

Gallati, R. (2003). Risk management and capital adequacy. New York: McGraw-Hill.

Greuning, V. H., \& Bratanvic, B. S. (2009). Analyzing banking risk: A framework for assessing corporate governance and risk management. Whashington, D.C.: The World Bank Publishing. http://dx.doi.org/10.1596/978-0-8213-7728-4

Helbok, G., \& Wagner, H. (2006). Determinants of operational risk reporting in the banking industry. Journal of Risk, 11, 25-37.

Jalal, A. (2011). Evaluating enterprise risk management (ERM); Bahrain financial Sectors as a case study. International Business Research, 4(3), 83-92. http://dx.doi.org/10.5539/ibr.v4n3p83

Kaplan, R. S. (2009). Risk management and the strategy execution system. Balanced Scorecard Report: The Strategy Execution Source. Harvard Business Publication and Palladium Group, Inc., 11(6), 1-16.

Kaplan, R. S. (2010). Harvard Professor Agrees that companies need a risk scorecard. Wheelhouse Advisors.

Kaplan, R. S., \& Norton, D. P. (1993). Putting the balance scorecard to work. Harvard Business Review, 71(5), 37-38.

Kaplan, R. S., \& Norton, D. P. (1996). Linking the balanced scorecard to strategy. California Management Review, 39(1), 65-66. http://dx.doi.org/10.2307/41165876

Kaplan, R. S., \& Norton, D. P. (1996). Using the Balanced Scorecard as a Strategic Management System. Harvard Business Review, 74(1), 75-85.

Kaplan, R. S., \& Norton, D. P. (2004). Strategy Maps-Converting Intangible Assets into tangible Outcomes. Harvard Business School press books.

Kransnikov, A., Jayachandran, S., \& Kumar, V. (2009). The Impact of Customer Relationship Management Implementation on cost and profit Efficiencies: Evidence from the US. Commercial Banking Industry. Journal of Marketing, 73, 61-76. http://dx.doi.org/10.1509/jmkg.73.6.61

Lhen, K., \& Makhija, A. K. (1996). EVA \& MVA as performance Measures and Signals for Strategic Change. Strategic Leadership, 24(3), 34-38. http://dx.doi.org/10.1108/eb054556

Mahbub, N., Paul, S. K., \& Azeem, A. (2013). A neural approach to product demand forecasting. International Journal of Industrial and Systems Engineering, 15(1), 1-18. http://dx.doi.org/10.1504/IJISE.2013.055508

Markowitz, H. (1952). Portfolio selection. Journal of Finance, 7(1), 77-91. http://dx.doi.org/10.2307/2975974

Marrison, C. (2002). The Fundamentals of Risk Measurement. New York: McGraw-Hill.

Mckinsey \& Company. (2013). Getting to ERM: A road Map for banks and Other Financial Institutions (pp. 1-15). 
Mckinsey Working Papers on Risk.

McNish, R., Schlosser, A., Selandari, F., \& Vorholt, J. (2013). Getting to ERM: A Road Map for Banks and Other Financial Institutions (pp. 1-15). Mckinsey Working Paperson Risk.

Meulbroek, L. K. (2002). A senior manager's guide to integrated risk management. Journal of Applied Corporate Finance, 14(4), 56-70. http://dx.doi.org/10.1111/j.1745-6622.2002.tb00449.x

Mike, A. (2005). Enterprise risk management in action (pp. 1-33). The London School of Economics and Political Science-ESRC Centre for Analysis of Risk and Regulation, Discussion Paper No. 35.

Mike, A. (2008). Risk management at crunch time: Are chief risk officers compliance champions or business partners? Harvard Business School Publishing, 1-19.

Mike, A., \& Kaplan, R. S. (2013). Towards a contingency theory of enterprise risk management (pp. 1-43). Harvard Business School Press Working Paper 13-063.

Nagumo, T. (2005). Aligning enterprise risk management with strategy through the BSC: The bank of Tokyo Mitsubishi approach. Balanced Scorecard Report: The Strategy Execution Source, Harvard Business Publication and Palladium Group, Inc., (7), 1-3.

Patuelli, R. R., \& NijKam, P. P. (2006). The development of regional employment in Germany: Results from neural network experiments. Scienzeregionali, 5(3).

Santomero, A. M. (1997). Commercial bank risk management: An analysis of the process. Journal of Financial Services Research, 12(2/3), 83-115. http://dx.doi.org/10.1023/A:1007971801810

Schroeck, G. (2002). Risk management and value creation in financial institutions. New Jersy: John Wiley \& Sons LTD.

Sharpe, W. J. (1964). Capital asset prices: A theory of market equilibrium under conditions of risk. Journal of Finance, 19(3), 425-442. http://dx.doi.org/10.2307/2977928

Sharpe, W., Alexander, G., \& Bailey, J. (1995). Investments Fifth Edition Prentice Hall. International Edition.

Srivastav, S. (2013). A study of enterprise risk Management in banks. Journal of Management-Gyanpratha -ACCMAN, 5(1), 1-10.

Wang, J. Z., Wang, J. J., Zhang, Z. G., \& Guo, S. P. (2011). Forecasting stock indices with back propagation neural network. Expert Systems with Applications, 38(11), 14346-14355. http://dx.doi.org/10.1016/j.eswa.2011.04.222

Waring, A., \& Glenden, A. I. (1998). Managing Risk. Thomson: Thomson Business Press.

Weissnrieder, F. (1997). Value Based Management: Economic Value added or cash value added? Gothenburg Studies in Financial Economics, 1-38. http://dx.doi.org/10.2139/ssrn.156288

Woods, M. (2008). Linking risk management to strategic controls: A case study of Tesco plc. Journal of Risk Assessment \& Management, 7(8), 6-7.

\section{Copyrights}

Copyright for this article is retained by the author(s), with first publication rights granted to the journal.

This is an open-access article distributed under the terms and conditions of the Creative Commons Attribution license (http://creativecommons.org/licenses/by/3.0/). 